\title{
Acceptance of Internet Banking among Consumers in Kota Damansara, Selangor, Malaysia
}

\author{
Mahiswaran Selvanathan ${ }^{1}$, Uma Devi Krisnan ${ }^{1} \&$ Goh Kar Jun ${ }^{1}$ \\ ${ }^{1}$ SEGi University, Malaysia \\ Correspondence: Mahiswaran Selvanathan, SEGi University, Malaysia. E-mail: mahiswaran@gmail.com
}

Received: September 30, 2016

Accepted: January 20, $2017 \quad$ Online Published: January 26, 2017

doi:10.5539/ijbm.v12n2p103

URL: http://dx.doi.org/10.5539/ijbm.v12n2p103

\begin{abstract}
The main objective of the study is to identify and analyse on the factors affecting adoption of Internet banking by bank consumers. The factors being analysed in this study are security, subjective norms, perceived relative advantage, and perceived ease of use. The study was conducted to achieve the objectives which have been set in this research. The research findings indicate that there is a relationship between subjective norms and perceived relative advantage towards the adoption of Internet banking. Meanwhile, security and perceived ease of use shows not significant towards the adoption of Internet banking.
\end{abstract}

Keywords: internet banking, security, subjective norms, relative advantage, ease of use

\section{Introduction}

The number of Malaysian Internet users has increased significantly in recent years. Based on Table 1, it is reported by the internet world stats that internet users in Malaysia has increased from approximately 3.7 million users in the year 2000 to approximately 17 million users in 2012 (Internet World Stats, 2012).

Table 1. Internet usage stats in Malaysia

\begin{tabular}{llll}
\hline Year & Users & Population & \% Penetration \\
\hline 2000 & $3,700,000$ & $24,645,600$ & $15.0 \%$ \\
2005 & $10,040,000$ & $26,500,699$ & $37.9 \%$ \\
2006 & $11,016,000$ & $28,294,120$ & $38.9 \%$ \\
2007 & $13,528,200$ & $28,294,120$ & $47.8 \%$ \\
2008 & $15,868,000$ & $25,274,133$ & $62.8 \%$ \\
2012 & $17,723,000$ & $29,179,952$ & $60.7 \%$ \\
\hline
\end{tabular}

Source: Internet World Stats, 2012.

In 2015, Malaysia has approximately 19 million internet banking subscribers (Chuan, 2015). The number of banks that offer internet banking features in Malaysia is 31 . Meanwhile, there are 13 banks only that offer services of mobile banking in Malaysia (Bank Negara Malaysia, 2015).

However, the traditional style retail banking remains its high demand and it is still the method used the most to conduct banking tasks in many countries. Many individuals are still reluctant to shift their traditional transactional activities towards internet banking. Malaysia remains a high number of users of cash and cheques despite the improvement achieved in the internet banking services and electronic payment infrastructure. The usage of cheques in Malaysia per capita has a reading of 6.9 compared to 0.2 in advanced countries (Bank Negara Malaysia, 2015).

Suganthi and Balachandran (2001) have conducted a study and found that out of the total respondents in their research, 20 percent of the respondents had already adopted internet banking services. In fact that internet banking was only started around 6 months in Malaysia that time, the result of the study seem to display a positive performance of internet banking in Malaysia. However, there were a study by Ramayah, Jantan, Nasser, Koay and Razli (2003) has showed the negative performance of internet banking in Malaysia. Ramayah et al (2003) have conducted a research to analyse the receptiveness of internet banking in Malaysia. 


\section{Research Objectives}

1) To find the relationship between perceived relative advantage and the adoption of Internet banking.

2) To find the relationship between security and the adoption of Internet banking.

3) To find the relationship between perceived ease of use and the adoption of Internet banking.

4) To find the relationship between subjective norms and the adoption of Internet banking.

\section{Literature Review}

\subsection{Internet Banking}

There are various different explanations and definitions for the term Internet banking. This is due to the fact that many different authors have different perspectives on what internet banking functions is and the pros and cons of internet banking. Internet banking is recognized also by several other terms such as electronic banking, ebanking and online banking. Yiu, Grant and Degar (2007) defined internet banking as the process of delivering banking services to customers in a specific internet platform. Daniel (1999) explains that in a basic view and perspective, internet banking can be described as the process of webpage establishment by banks to provide information about their banking products and services. The financial and banking industry has been transformed in terms of the core of their products and services and the packaging, delivery and consumption method (Sathye, 1999).

\subsection{Perceived Relative Advantage}

According to researcher, the relative advantage generated from an innovation has a positive relationship with the rate of adoption (Gherib, 2015). The customers require certain reasons such as the gaining of relative advantage in order for customers to use the new technology innovation (Azad, Abbaszadeh, Rikhtegar, \& Asgari, 2013). Through the utilization of internet banking, it enables customers to gain access of their banking accounts without being affected by the time and geographical factor. Customers will be able to conduct transactions and check on their banking accounts anytime and anywhere. Internet banking also provides customers with greater ability to manage their banking accounts and finances as it became easier for customers to have access to their bank accounts. Thus, in the perspective of individuals, if internet banking provides advantages, individuals will be influenced towards adopting the innovation (Nasri \& Charfeddine, 2012).

H1: There is a positive relationship between perceived relative advantage and the adoption of Internet banking.

\subsection{Security}

According to Daniel (1999), the adoption and acceptance of new innovation by consumers is also affected by the perceived security factor. The perceived security factor is the main factor that slows down the adoption process on internet banking in various countries (Hojjati, Monavvarian, \& Roozbahani, 2015). This is due to the fact that consumers are concern on the reliability of the financial institutions in providing consistent security of financial transactions conducted over the internet. This is due to the situation in which customers have fear in exposing their financial activities to risks. The violation of security in internet banking can cause critical problems including disturbance of information access and also the failure of operating system (Ameme, 2015). The perceived security factor plays a vital role in building trust of consumers on internet banking (Popoola \& Arshad, 2015). This is due to the existing risks that are needed to be faced by consumers in conducting financial transactions online.

$\mathrm{H} 2$ : There is a positive relationship between security and the adoption of Internet banking.

\subsection{Perceived Ease of Use}

Perceived ease of use is defined by Davis as perception and view of consumers on the level of complexity and easiness in using a system or an innovation towards individuals expecting minimum or zero effort to use a specific innovation or system (Davis, 1989). Ease of use is identified as an essential variable that affects the customers' rate of adoption of new innovation (Dover, 1988). There are some services in the internet banking that are difficult and complex to be used. According to this context, there is an online research conducted by Cyber Dialogue, identified that up to three million individuals from the United States have stopped using online banking method due to the complicated and less ease of use of the internet banking ("The Ultimate Guide to Business and Technology of Online Banking", 2013). A study in the United Kingdom stated that how easy to use a new innovation is one of the main variables that affect the customer's adoption on internet banking (Daniel, 1999). It is logical to state that the easier to use of an innovation, the higher the rate of adoption. It is suggested that it is important that the internet is not complicated to be used in order to encourage more internet banking adoption (Nasri \& Charfeddine, 2012). 
The understanding of consumers on an innovation or system is an important component in determining the adoption of the innovation by consumers. The easier to use and understood the system is, the higher the probability of adoption by consumers (Alwan \& Al-Zu'bi, 2015). This leads to the result stating that the perceived easiness to use is positively related to the consumers' adoption on internet banking (Rawashdeh, 2015). It is explained that the ease of use of the nature of an innovation will directly affect the acceptance of the innovation (Fang, Chan, Brzezinski, \& Xu, 2005). Additionally, simple, easy and user-friendly innovations such as the clarity of command and steps, simple content and visible graphical layouts significantly enhance the ease of use of the innovation and contribute in encouraging the adoption (Fo \& Ak, 2015). Numerous researches proofed that the perceived ease of use of an innovation directly influences the acceptance and adoption towards internet banking. Jahangir \& Parvez (2012) findings indicates that the perceived ease of use is one of the most vital factor that boost the usage of information technologies and affect the internet banking adoption.

The perception of the customers on the ease of use of the innovation is important in determining the acceptance of the system by the customers (Mann \& Sahni. 2012). Besides that, the intention of customers in using a system will be influenced by its perceived ease of use as well (Teoh, Chong, Lin, \& Chua, 2013). Previous studies have also identified that there is a positive relationship between perceived ease of use and the adoption of internet banking. Amin (2007) stated that there is a positive causality between the perceived ease of use and the innovation and system adoption. A system that requires lesser effort to be operated will be more likely to be accepted and adopted by customers (Gefen \& Straub, 2000). In another research, Lee, Fiore, and Kim (2006) also stated that the perceived ease of use has a positive impact on the initial willingness and acceptance of consumers in adopting an innovation. It is stated that the perceived ease of use has a positive relationship with the adoption of internet banking. Hence, it can be concluded that the perceived ease of use significantly affected the adoption on internet banking (Lau, 2002).

H3: There is a positive relationship between perceived ease of use and the adoption of Internet banking.

\subsection{Subjective Norms}

Subjective norms can be defined as the view of an individual that has close relationship with the individual thinking whether should or should not the individual carry out the behavior in question (Fishbein \& Ajzen, 1975). Social norm is identified as the external influence and point of view. In certain researches, subjective norm is also known as social norm (Yi, Jackson, Park, \& Probst, 2006). There are various researches and studies that have identified that social norms played a vital role in affecting the adoption of internet banking. The results of the study conducted by Fo and Ak (2015) in Nigeria has indicated that the subjective norms factor is positively affecting the adoption of Internet banking by customers.

Subjective norm functions as an important role in encouraging adoption of various innovations and systems. For example, subjective norm has been one of the factor contributing in various new technology such as mobile payment (Yan, Nor, Abushanad, \& Sutanonpaib, 2009). Besides that, subjective norm is also one of the variables contributing in the adoption of e- tax payment (Ramayah, Yusoff, Jamaludin, \& Ibrahim, 2009). Subjective norm has a positive relationship with the customers' intention to maintain the using of retail banking services (Ravi, Carr, \& Sagar, 2007). The words of mouth, opinions and advices from peers, family and friends will influence an individual's decision in adopting a new innovation (Riquelmi, \& Rios, 2010).

In a Malaysian point of view, there is a research stating that the social norm factor is the main influencer towards the adoption of mobile banking (Kleijnen, Wetzels, \& Ruyter, 2004). The subjective norms are stated to be more efficient and powerful towards new and potential adopters (Nasir, Wu, Yago, \& Li, 2015). This is due to the fact that new and potential adopters and users are lack of self-experience. Hence, potential users tend to rely on others' advices and information before adopting an innovation. The groups that are possible in influencing an individual's adoption on specific product or services include the individual's family, friends and peers (Tan, \& Teo, 2000).

There is a significant relationship between the influence from family, friends and peers and the subjective norm (Agarwal, Rastogi, \& Mehrotra, 2009). Puschel and Mazzon (2010) stated that there is a positive relationship between the social norm factor and the adoption of an innovation. Similarly, it is stated by Schepers and Wetzels (2007) that the subjective norms have significant positive relationship with the consumers' adoption.

H4: There is a positive relationship between subjective norms and the adoption of Internet banking.

\section{Findings}

The Pearson Correlation Coefficient employed to indicate the relationship between adoption and independent variables. The result was presented in Table 2. 
Table 2. The Pearson correlation coefficient for adoption

\begin{tabular}{|c|c|c|c|c|c|}
\hline & Adoption & Securit & $\begin{array}{l}\text { Subjective } \\
\text { Norms }\end{array}$ & $\begin{array}{l}\text { Relative } \\
\text { Advantage }\end{array}$ & $\begin{array}{l}\text { Perceived Ease Of } \\
\text { Use }\end{array}$ \\
\hline \multirow[t]{3}{*}{ Adoption } & Pearson Correlation 1 & .057 & $.716^{* *}$ & $.653^{* *}$ & .130 \\
\hline & Sig. (2-tailed) & .534 & .000 & .000 & .159 \\
\hline & $\mathrm{N}$ & 120 & 120 & 120 & 120 \\
\hline \multirow[t]{3}{*}{ Security } & Pearson Correlation & 1 & .052 & .127 & .101 \\
\hline & Sig. (2-tailed) & & .571 & .166 & .272 \\
\hline & $\mathrm{N}$ & 120 & 120 & 120 & 120 \\
\hline \multirow[t]{3}{*}{ Subjective Norms } & Pearson Correlation & & 1 & $.725^{* *}$ & $.198^{*}$ \\
\hline & Sig. (2-tailed) & & & .000 & .030 \\
\hline & $\mathrm{N}$ & & 120 & 120 & 120 \\
\hline Relative & Pearson Correlation & & & 1 & 169 \\
\hline \multirow[t]{2}{*}{ Advantage } & Sig. (2-tailed) & & & & .065 \\
\hline & $\mathrm{N}$ & & & 120 & 120 \\
\hline \multicolumn{4}{|c|}{ Perceived Ease OfPearson Correlation } & & 1 \\
\hline \multirow[t]{2}{*}{ Use } & Sig. (2-tailed) & & & & \\
\hline & $\mathrm{N}$ & & & & 120 \\
\hline
\end{tabular}

**. Correlation is significant at the 0.01 level (2-tailed).

*. Correlation is significant at the 0.05 level (2-tailed).

Table 2 shows the results of correlation between the dependent variable and independent variables which are used to examine the hypothesis in this research. The Internet Banking adoption indicates a moderate correlation with security. Meanwhile, it shows very low correlation with the subjective norms and relative advantage and indicates a low correlation with the perceived ease of use. Security shows a moderate correlation with adoption and subjective norms. Meanwhile, security indicates a low correlation with relative advantage and perceived ease of use.

Subjective norm shows very low correlation with adoption and relative advantage. Meanwhile it indicates a moderate correlation with security and shows a low correlation with perceived ease of use. Relative advantage shows a very low correlation with adoption and also subjective norms. Meanwhile it indicates a low correlation with security and perceived ease of use. Perceived ease of use indicates a low correlation with all variables which are adoption, security, subjective norms and also relative advantage.

Table 3. Hypothesis results for multiple regression analysis

\begin{tabular}{llll}
\hline Independent Variable & Standardized Coefficient & Significant Value & $\mathbf{R}^{\mathbf{2}}$ \\
\hline Security & -.004 & .953 & \\
Subjective Norms & .514 & .000 & 0.551 \\
Relative Advantage & .285 & .002 & \\
Perceived Ease of Use & -.020 & .756 & \\
\hline
\end{tabular}

As shown in Table 3, the value of ' $R$ square' is .551 . This represents that $55 \%$ of the total variance in the dependent variable (Internet banking adoption) is described by the total independent variables (security, subjective norms, relative advantage and perceived ease of use). Therefore, the remaining $45 \%$ might be accounted by other variables excluded from this research. The composition of the force among independent variables (security, social norms, relative advantage, and perceived ease of use) that contributes to the dependent variable (internet banking adoption) are subjective norms $(B=.514)$, relative advantage $(B=.285)$, security $(\mathrm{B}=-.004)$, perceived ease of use $(\mathrm{B}=-.020)$.

The significant value for each variable will show whether the variable contribute statistically towards the similarity. If the significant value is lower than .05, hence, the hypothesis will be accepted. As shown in Table 4, $\mathrm{H} 2$ and $\mathrm{H} 3$ are accepted, meanwhile $\mathrm{H} 1$ and $\mathrm{H} 4$ are rejected. 
Table 4. Hypothesis testing results

\begin{tabular}{|c|c|c|}
\hline \multicolumn{2}{|c|}{ Hypothesis } & \multirow{2}{*}{$\begin{array}{l}\text { Results } \\
\text { Rejected }\end{array}$} \\
\hline H1: & H1: There is a positive relationship between security and the adoption of Internet banking. & \\
\hline $\mathrm{H} 2$ : & $\begin{array}{l}\text { H2: There is a positive relationship between subjective norms and the adoption of Internet } \\
\text { banking. }\end{array}$ & Accepted \\
\hline H3: & $\begin{array}{l}\text { H3: There is a positive relationship between relative advantage and the adoption of Internet } \\
\text { banking. }\end{array}$ & Accepted \\
\hline H4: & $\begin{array}{l}\text { H4: There is a positive relationship between perceived ease of use and the adoption of } \\
\text { internet banking. }\end{array}$ & Rejected \\
\hline
\end{tabular}

\section{Discussion and Conclusion}

\subsection{Relationship between Perceived Relative Advantage and the Adoption of Internet Banking}

One of the objectives of the research is to find the relationship between the perceived relative advantage and the adoption of Internet banking. The hypothesis of this research has stated that there is a positive relationship between perceived relative advantage and the adoption of Internet banking. This hypothesis is supported by various authors in their research studies. Sathye (1999) has stated in their journal that perceived relative advantage is a vital factor that has a positive relationship with the adoption of Internet banking. Besides that, Jaruwachirathanakul and Fink (2005) have also stated in their study that there is a positive relationship between the perceived relative advantage and the adoption of Internet banking. In another study by Moore and Benbasat (1991), the study also indicates that perceived relative advantage on technological innovation affect the adoption rates on the innovation positively. In fact, the hypothesis stating that there is a positive relationship between perceived relative advantage and the adoption of Internet banking has been accepted in this research study.

\subsection{Relationship between Security and the Adoption of Internet Banking}

Another objective of this research is to find the relationship between security and the adoption of Internet banking. The hypothesis of this research stated that there is a positive relationship between the security and the adoption of Internet banking. This hypothesis is supported by various researchers in their studies. According to Hojjati, Monvvarian, and Roozbahani (2015), the researchers have stated that there is a direct relationship between security and the adoption of Internet banking. Besides that, a study conducted in Poland by Polasik and Wisniewski (2009) stated that there is a positive relationship between security and the adoption of Internet banking. Cunningham (2003) also concluded that there is a positive relationship between security and the adoption of Internet banking. However, the hypothesis stating that there is a positive relationship between security and the adoption of Internet banking has been rejected in this research.

\subsection{Relationship between Perceived Ease of Use and the Adoption of Internet Banking}

The objective of this research is also to find the relationship between the perceived ease of use and the adoption of Internet banking. The hypothesis of this research stated that there is a positive relationship between perceived ease of use and the adoption of Internet banking. Some researchers have supported this hypothesis in their own research studies. Nasri and Charfeddine (2012) have stated in their research that, there is a positive relationship between perceived ease of use and the adoption of Internet banking. Meanwhile, Rawashdeh (2015) also stated that perceived ease of use is positively related to the adoption on internet banking. Besides that, Mann and Sahni (2012) stated that the perceived ease of use is positively affecting the adoption of Internet banking. However, this hypothesis is rejected in this research.

\subsection{Relationship between Subjective Norms and the Adoption of Internet Banking}

Another objective of this research is to find the relationship between subjective norms and the adoption of Internet banking. There are various researches and studies that have identified that social norms played a vital role as one of the variables affecting the adoption of internet banking. The results of the study conducted by Fo and Ak (2015) in Nigeria has indicated that there is a positive relationship between the subjective norms factor and the internet banking adoption by customers. Puschel and Mazzon (2010) stated that there is a positive relationship between the subjective norm factor and the adoption of Internet banking. Similarly, it is stated by Schepers and Wetzels (2007) that the subjective norms have significant positive relationship with the consumers' adoption. The hypothesis stating that there is a positive relationship between subjective norms and the adoption of Internet banking is accepted in this research. 


\section{References}

Agarwal, R., Rastogi, S., \& Mehrotra, A. (2009). Customers' perspectives regarding e-banking in an emerging economy. Journal of Retailing and Consumer Services, 16(5), 340-351. https://doi.org/10.1016/j.jretconser.2009.03.002

Alwan, H. A., \& Al-Zu'bi, A. I. (2015). Determinants of Internet Banking Adoption among Customers of Commercial Banks: An Empirical Study in the Jordanian Banking Sector. International Journal of Business and Management, 11(3).

Ameme, B. K. (2015). The impact of customer demographic variables on the adoption and use of internet banking in developing economies. Journal of Internet Banking and Commerce.

Amin, H. (2007). Internet banking adoption among young intellectuals. Journal of Internet Banking and Commerce, 12(3), 1-13.

Azad, N., Abbaszadeh, V., Rikhtegar, M., \& Asgari, H. (2013). An empirical investigation on factors influencing on electronic banking for developing export. Management Science Letters, 1583-1586. https://doi.org/10.5267/j.msl.2013.05.032

Bank Negara Malaysia. (2015). Retrieved from BNM: http://www.bnm.gov.my/index.php?ch=en_speech\&pg=en_speech_all\&ac $=492$

Chuan, T. N. (2015). Bank Negara Malaysia. Retrieved from BNM: http://www.bnm.gov.my/documents/conference_vol/2015_PaymentSystem/1.\%20Outcomes\%20of\%20Reg ulatory\%20Measures $\% 20$ on $\% 20$ the $\% 20$ Payment $\% 20$ Landscape.pdf

Cunningham, J. (2003). The diffusion of Internet banking among Singapore consumers. International Journal of Bank Marketing, 16-28.

Daniel, E. (1999). Provision of electronic banking in the UK and the Republic of Ireland. International Journal of bank marketing, 17(2), 72-83. http://dx.doi.org/10.1108/02652329910258934

Davis, F. D. (1989). Perceived Usefulness, Perceived Ease of Use, and User Acceptance of Information Technology. MIS quarterly, 319-340. https://doi.org/10.2307/249008

Dover, P. (1988). The Effect of Technology Selection on Consumer Adoption of the In-home Computerized Banking. International Journal of Bank Marketing, 31-37. https://doi.org/10.1108/eb010829

Fang, X., Chan, S., Brzezinski, J., \& Xu, S. (2005). Moderating effects of task type on wireless technology

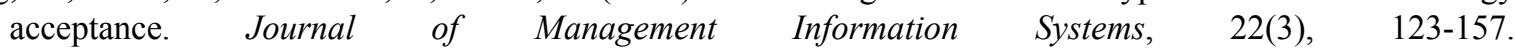
https://doi.org/10.2753/MIS0742-1222220305

Fishbein, M., \& Ajzen, I. (1975). Belief, Attitude, Intention and Behavior: An Introduction to Theory and Research. Boston, MA: Addison-Wesly.

Fo, O., \& Ak, A. (2015). Factors Influencing Intention to Adopt Internet Banking by Postgraduate Students of the University of Ibadan, Nigeria. Journal of Internet Banking \& Commerce, 20(3). https://doi.org/10.4172/1204-5357.1000123

Gefen, D., \& Straub, D. (2000). The relative importance of perceived ease of use in IS adoption: A study of e-commerce adoption. Journal of the Association for Information Systems, 1(8), 1-28.

Gherib, D. (2015). Top Management Characteristics and Adoption of Internet Banking: Case Study of the Tunisian Banking Sector. International Journal of Innovation and Applied Studies, 377-383.

Hojjati, S. N., Monavvarian, A., \& Roozbahani, F. S. (2015). Evaluation of Factors Influencing Internet Banking Acceptance by Internet Users in Iran. International Journal Advanced Networking and Applications, 6(6), 2503-2519.

Internet World Stats. (2012). Retrieved from Internet World Stats: http://www.internetworldstats.com/asia/my.htm

Jahangir, N., \& Parvez, N. (2012). Factors determining customer adaptation to internet banking in the context of private commercial banks of Bangladesh. Business Perspectives and Research, 25-36.

Jaruwachirathanakul, B., \& Fink, D. (2005). Internet banking adoption strategies for a developing country: the case of Thailand. Internet Research, 295-311. https://doi.org/10.1108/10662240510602708 
Kleijnen, M., Wetzels, M., \& Ruyter, K. D. (2004). Consumer acceptance of wireless finance. Journal of Financial Services Marketing , 8(3), 206-217. https://doi.org/10.1057/palgrave.fsm.4770120

Lau, A. S. (2002). Strategies to motivate brokers adopting on-line trading in Hong Kong financial market. Review of Pacific Basin Financial Markets and Policies, 471-489. https://doi.org/10.1142/S0219091502000894

Lee, H. H., Fiore, A., \& Kim, J. (2006). The role of the technology acceptance model in explaining effects of image interactivity technology on consumer responses. International Journal of Retail \& Distribution Management, 34(8), 621-644. https://doi.org/10.1108/09590550610675949

Mann, B. J., \& Sahni, S. K. (2012). Profiling Adopter Categories of Internet Banking in India: An Empirical Study, 16(4), 283-295. http://dx.doi.org/10.1177/0972262912460187

Moore, G., \& Benbasat, I. (1991). Development of an instrument to measure the perceptions of adopting an information technology innovation. Information Systems Research, 192-223. https://doi.org/10.1287/isre.2.3.192

Nasir, M. A., Wu, J., Yago, M., \& Li, H. (2015). Influence of Psychographics and Risk Perception on Internet Banking Adoption: Current State of Affairs in Britain. International Journal of Economics and Financial Issues, 461-468.

Nasri, W., \& Charfeddine, L. (2012). Factors affecting the adoption of Internet banking in Tunisia: An integration theory of acceptance model and theory of planned behavior. Journal of High Technology Management Research, 1-14. https://doi.org/10.1016/j.hitech.2012.03.001

Polasik, M., \& Wisniewski, P. T. (2009). Empirical analysis of Internet banking in Poland. International Journal of Bank Marketing, 32-52. https://doi.org/10.1108/02652320910928227

Popoola, N. F., \& Arshad, R. B. (2015). Strategic approach to build customers trust in adoption of internet banking in Nigeria. Journal of Internet Banking and Commerce, 20(1).

Puschel, J., \& Mazzon, J. A. (2010). Mobile banking: Proposition of an integrated adoption intention framework. International Journal of Bank Marketing, 28(5), 389-409. https://doi.org/10.1108/02652321011064908

Ramayah, T., Jantan, M., Nasser, M. N., Koay, P. L., \& Razli, C. R. (2003). Receptiveness of internet banking by Malaysian consumers: The case of Penang. Asian Academy of Management Journal, 8(2), 1-29.

Ramayah, T., Yusoff, Y. M., Jamaludin, N., \& Ibrahim, A. (2009). Applying the theory of planned behavior (TPB) to predict internet tax filing intentions. International Journal of Management, 26(2), 272.

Ravi, V., Carr, M., \& Sagar, N. V. (2007). Profiling of Internet Banking Users in India Using Intelligent Techniques. Journal of Services Research, 61- 73.

Rawashdeh, A. (2015). Factors affecting adoption of internet banking in Jordan. International Journal of Bank Marketing, 33(4), 510-529. https://doi.org/10.1108/IJBM-03-2014-0043

Riquelme, H. E., \& Rios, R. E. (2010). The moderating effect of gender in the adoption of mobile banking. International Journal of bank marketing, 28(5), 328-341. https://doi.org/10.1108/02652321011064872

Sathye, M. (1999). Adoption of Internet banking by Australian consumers: An empirical

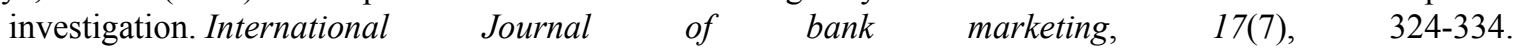
https://doi.org/10.1108/02652329910305689

Schepers, J., \& Wetzels, M. (2007). A meta-analysis of the technology acceptance model: Investigating subjective norm and moderation effects. Information \& management, 44(1), 90-103. https://doi.org/10.1016/j.im.2006.10.007

Sugathi, B., \& Balachandran. (2001). Internet banking patronage: an empirical investigation of Malaysia. Journal of Internet Banking and Commerce, 6(1). https://doi.org/10.1108/IntR-09-2012-0199

Tan, M., \& Teo, T. S. (2000). Factors influencing the adoption of Internet banking. Journal of the AIS, $1(1 \mathrm{es}), 5$.

Teoh, W. M., Chong, S. C., Lin, B., \& Chua, J. W. (2013). Factors affecting consumers' perception of electronic payment: an empirical analysis. Internet Research, 465-485.

Yan, A., Md Nor, K., Abushanab, E., \& Sutanonpaib. (2009). Factors that affect mobile telephone users to use mobile payment solution. Journal of Economics and Management, 3(1), 37-49. https://doi.org/10.1016/j.ijinfomgt.2007.03.002 
Yiu, C. S., Grant, K., \& Degar., D. (2007). Factors affecting the adoption of Internet. International Journal of Information Management, 27(5), 330-351.

\section{Copyrights}

Copyright for this article is retained by the author(s), with first publication rights granted to the journal.

This is an open-access article distributed under the terms and conditions of the Creative Commons Attribution license (http://creativecommons.org/licenses/by/4.0/). 